\title{
Harmonisasi Kewenangan Lembaga Penyelenggaraan Pelayanan Perizinan Terpadu
}

\author{
Solechan, Edgar Wilardi \\ Fakultas Hukum, Universitas Diponegoro \\ solechan@live.undip.ac.id
}

\begin{abstract}
This study aims to assess the harmonization of the authority of the organization of integrated licensing services. The research method used is a legal research method that focuses on the implementation of licensing principles. The results showed that licensing and non-licensing services in the One-Stop Integrated Service System (PTSP), including the Regional Government, had separate authority in regional units, including licensing and non-licensing various fields. Regulations concerning PTSP implementation, such as HR, Finance and Supervision, in addition to the institutional form is still in the level where SKPD is intersects with KP2T in the area has been in the form of Dinas or Agency. Therefore, PTSP implementation in the future will run optimally in serving the community.
\end{abstract}

Keywords: Authority, One-Stop Integrated Services, Public Services.

\begin{abstract}
Abstrak
Penelitian ini bertujuan untuk mengethui harmonisasi kewenangan lembaga penyelenggaraan pelayanan perizinan terpadu. Metode penelitian yang digunakan adalah metode penelitian hukum yang meniti beratkan pada pelaksanaan prinsip prinsip perizinan. Hasil penelitian menunjukan bahwa kegiatan pelayanan perizinan dan non perizinan di daerah telah diatur untuk menggunakan sistem Pelayanan Terpadu Satu Pintu (PTSP), tidak terkecuali Pemerintah Daerah yang telah mendelegasikan kewenangan tersebut kepada unit perangkat daerah tersendiri, termasuk perizinan dan non perizinan di berbagai bidang. Pengaturan mengenai PTSP di daerah tidak mengatur secara detail beberapa aspek penting pelaksanaan PTSP itu sendiri seperti SDM, Keuangan dan Pengawasan, selain itu bentuk kelembagaannya masih setingkat kantor dimana notabene SKPD teknis yang bersinggungan dengan KP2T di daerah telah berbentuk Dinas atau Badan yang mengakibatkan kesenjangan eselon pimpinan. Oleh karenanya diperlukan perubahan terhadap pengaturan pelaksanaan PTSP di daerah kedepannya agar dapat berjalan dengan optimal dalam melayani masyarakat.
\end{abstract}

Kata Kunci : Kewenangan, Pelayanan Terpadu Satu Pintu, Pelayanan Publik.

\section{A. Pendahuluan}

Pelayanan publik / masyarakat merupakan salah satu tugas, penyelenggara pemerintah daerah, ini sebagai kewajiban pemerintah dan sebaliknya sebagai hak bagi warga masyarakat/publik, semua hak dan kewajiban diatas berlaku sebaliknya yang mencakup pelaksanaan pelayanan, pengelolaan, pengaduan publik, informasi, pengawasan, penyuluhan dan konsultasi diatur dalam Undang-Undang Nomor 25 Tahun 2009. Penyelenggaraan pemerintah daerah berkenaan dengan pelayanan publik 
tersebut berfokus pada pelayanan kepada publik/masyarakat, terutama berkenaan dengan pangan, sandang, papan, pendidikan kesehatan, lindungan pekerjaan, dan bidang sosial. Inilah, yang perlu masyarakat prioritas dari penyelenggaraan pemerintah daerah.

Negara Republik Indonesia sebagai Negara kesatuan menganut asas Desentralisasi dalam penyelenggaraan pemerintahan dengan memberikan kesempatan dan keleluasaan kepada daerah untuk menyelenggarakan Otonomi daerah.

Penyelenggaraan otonomi daerah sebagaimana telah diamanatkan secara jelas di dalam UUD 1945, ditujukan untuk menata sistem pemerintahan daerah dalam kerangka Negara Kesatuan Republik Indonesia. Pelaksanaannya dilakukan dengan memberikan keleluasaan kepada daerah untuk menyelenggarakan kewenangan pemerintahan ditingkat daerah. Dalam rangka melaksanakan amanat UUD 1945, dimaksud telah ditetapkan Undang-Undang tentang Pemerintahan Daerah yang dalam perjalanan sejarahnya telah mengalami beberapa kali perubahan.

Semenjak bermulanya Otonomi Daerah, belum tercapai konsensus mengenai model pelaksanaan otonomi daerah yang efisien dan tepat sasaran. Hal ini tampak jelas dari keputusan pemerintah untuk merevisi Undang- undang Nomor 22 Tahun 1999 dan Undang-undang Nomor 25 Tahun 1999 dengan membuat Undang-undang Nomor 32 Tahun 2004 tentang Pemerintahan Daerah dan Undang-undang Nomor 33 Tahun 2004 tentang Perimbangan Keuangan antara Pemerintah Pusat dan Pemerintah Daerah, karena dianggap mengancam harmonisasi pelaksanaan kebijakan. Namun demikian, tetap saja masih terdapat banyak pemikiran dan penafsiran pakar ekonomi publik dan pemerintah daerah yang belum terakomodasi.

Dalam bidang investasi, pelaksanaan Otonomi Daerah mengakibatkan timbulnya permasalahan-permasalahan yang mengakibatkan investor asing enggan menanamkan modalnya di Indonesia. Pelaksanaan otonomi yang terkesan setengah matang menciptakan ketidakpastian biaya dan lamanya waktu berurusan dengan perizinan dan birokrasi bahkan kebijakan Otonomi Daerah. Deregulasi dan debirokratisasi pelayanan terpadu (one stop service) oleh beberapa badan, dinas dan kantor terkait dalam bidang perizinan maupun dalam bidang yang lain merupakan hal yang sangat mendesak dalam kaitannya mempercepat pembangunan ekonomi kerakyatan dan pengentasan kemiskinan.

Dalam Pasal 26 Ayat 2 Undang-undang Nomor 25 Tahun 2007 tentang Penanaman Modal disebutkan bahwa Pelayanan Terpadu Satu Pintu dilakukan oleh lembaga atau instansi yang berwenang di bidang penanaman modal yang mendapat pendelegasian atau pelimpahan wewenang dari lembaga atau instansi yang memiliki kewenangan perizinan dan non perizinan di tingkat pusat atau lembaga atau daerah 
yang berwenang mengeluarkan perizinan dan non perizinan di provinsi atau kabupaten / kota. Kemudian pada Ayat 3 disebutkan bahwa ketentuan mengenai tata cara dan pelaksanaan Pelayanan Terpadu Satu Pintu tersebut diatur dengan Peraturan Presiden. Selain dengan pembentukan PTSP, maka perlu didorong implementasi pelayanan publik di masing-masing daerah yang nyatanya hingga saat ini belum secara utuh dilakukan. Salah satu kendala yang ada adalah pendelegasian kewenangan Kepala Daerah dari Satuan Kerja Perangkat Daerah (SKPD) yang menyelenggarakan perizinan dan non perizinan kepada lembaga PTSP.(Febliany, Fitriyah \& Paselle 2014)

Pelayanan perizinan dengan sistem terpadu satu pintu (one stop service) ini membuat waktu pembuatan izin menjadi lebih singkat. Pasalnya, dengan pengurusan administrasi berbasis teknologi informasi, input data cukup dilakukan sekali dan administrasi dapat dilakukan secara simultan.

Dengan adanya kelembagaan PTSP, seluruh perizinan dan non perizinan yang menjadi kewenangan Kabupaten / Kota dapat terlayani dalam satu lembaga. Tanpa otoritas yang mampu menangani semua urusan tersebut instansi pemerintah tidak dapat mengatur pelbagai pengaturan selama proses. Oleh sebab itu, dalam hal ini instansi tersebut tidak dapat menyediakan semua bentuk perizinan yang diperlukan dalam berbagai tingkat administrasi, sehingga harus bergantung pada otoritas lain.

Ada pula yang disebut dengan standar pelayanan publik, yaitu ukuran yang dibakukan dalam penyelenggaraan pelayanan publik yang wajib ditaati oleh pemberi dan / atau penerima pelayanan. Menurut Keputusan Menteri Pendayagunaan Aparatur Negara Nomor 63 Tahun 2003, standar pelayanan sekurang-kurangnya meliputi :

1. Prosedur Pelayanan. Prosedur pelayanan yang dibakukan bagi pemberi dan penerima pelayanan termasuk pengaduan.

2. Waktu Penyelesaian. Waktu penyelesaian yang ditetapkan sejak saat pengajuan permohonan sampai dengan penyelesaian pelayanan termasuk pengaduan.

3. Biaya Pelayanan. Biaya / tarif pelayanan termasuk rinciannya yang ditetapkan dalam proses pemberian pelayanan.

4. Produk Pelayanan. Hasil pelayanan yang akan diterima sesuai dengan ketentuan yang telah ditetapkan.

5. Sarana dan Prasarana. Penyediaan sarana dan prasarana pelayanan yang memadai oleh penyelenggara pelayanan publik.

6. Kompetensi Petugas Pemberi Pelayanan. Kompetensi petugas pemberi pelayanan harus ditetapkan dengan tepat antara lain berdasarkan pengetahuan, keahlian, keterampilan, sikap dan perilaku yang dibutuhkan. 
Dengan demikian berdasarkan uraian tersebut maka, tulisan ini hendak menguraikan tentang harmonisasi kewenangan lembaga penyelenggaraan pelayanan perizinan terpadu. Untuk menjelasakan secara detail terkait dengan tema, maka akan diuraikan tentang pelayanan publik, prinsip pelayanan publik dan harmonisasi pelayanan publik terdahap implementasi prinsip pelayanan publik itu sendiri.

\section{B. Pembahasan}

\section{Pelayanan Publik}

Pemberian pelayanan publik oleh aparatur pemerintah kepada masyarakat sebenarnya merupakan implikasi dari fungsi aparat negara sebagai pelayan masyarakat dengan tujuan untuk mewujudkan kesejahteraan rakyat. Karena itu, kedudukan aparatur pemerintah dalam pelayanan umum (public services) sangat strategis karena akan sangat menentukan sejauh mana pemerintah mampu memberikan pelayanan yang sebaik-baiknya bagi masyarakat, dengan demikian akan menentukan sejauh mana negara telah menjalankan perannya dengan baik sesuai dengan tujuan pendiriannya untuk mewujudkan kesejahteraan bagi rakyatnya sebagaimana tertuang dalam konsep "welfare state”. (Nuriyanto 2014)

Menyoal peraturan perundang-undangan, UU RI No 25 Tahun 2009 tentang Pelayanan Publik Pasal 1 ayat 1 disebutkan bahwa Pelayanan Publik adalah kegiatan atau rangkaian kegiatan dalam rangka pemenuhan kebutuhan pelayanan sesuai dengan peraturan perundang-undangan bagi setiap warga Negara dan penduduk atas barang, jasa, dan atau pelayanan administratif yang disediakan oleh penyelenggara pelayanan publik.

Pelayanan publik merupakan isu utama (Main Issue) dalam ranah kebijakan publik. Hampir di seluruh sektor publik/sektor pemerintahan pelayanan publik sebagai wacana yang tanpa ujung. Pemerintah Banyak menjanjikan keringanan yang pada akhirnya berujung pada kekecewaan masyarakat terhadap pemerintah. Pelayanan publik menjadi isu kebijakan yang semakin strategis karena perbaikan pelayanan publik cenderung "berjalan di tempat" sedangkan implikasinya sangatlah luas dalam kehidupan ekonomi, politik, sosial budaya dan sebagainya.

Menanggapi persoalan-persoalan yang dihadapi mengenai pelayanan publik, maka Marom (Marom 2015) mengemukakan terdapat lima prinsip yang harus diperhatikan bagi para pelayan publik agar kualitas layanan dapat dicapai antara lain:

1. Tangible (terjamah): Kemampuan fisik, peralatan, personil dan komunikasi material

2. Realiable (handal): kemampuan membentuk pelayanan yang dijanjikan dengan tepat dan memiliki keajegan 
3. Responsiveness (pertanggungjawaban): yakni rasa tanggung jawab pemerintah terhadap mutu pelayanan

4. Assurance (jaminan): pengetahuan, perilaku, dan kemampuan pegawai.

5. Empathy (empati): perhatian perorangan pada pelanggan

Valerie A. Zeithaml et al (1990) mengonsepsikan mutu layanan publik pada dua pengertian yaitu expected service dan perceived service ${ }^{1}$. Keduanya terbentuk oleh dimensi-dimensi mutu layanan, yaitu:

1. Tangibles (terjamah)

2. Rehability (andal)

3. Responsiveness (tanggap)

4. Competence (kompeten)

5. Courtesy (ramah)

6. Credibility (bisa dipercaya)

7. Security (aman)

8. Acces (akses)

9. Communication (komunikasi)

10. Understanding the customer (memahami pelanggan)

Daripada itu, expected service juga dipengaruhi oleh:

1. Word of mouth (kata-kata yang diucapkan)

2. Personal needs (kebutuhan pribadi)

3. Past experience (pengalaman masa lalu)

4. External communications (komunikasi

Untuk dapat memberikan pelayanan yang memuaskan bagi pengguna jasa, penyelenggaraan pelayanan harus memenuhi asas-asas pelayanan yang berdasarkan Keputusan Menteri Pendayagunaan Aparatur Negara Nomor 63 Tahun 2003 meliputi :

a) Transparansi. Bersifat terbuka, mudah dan dapat diakses oleh semua pihak yang membutuhkan dan disediakan secara memadai serta mudah dimengerti.

b) Akuntabilitas. Dapat dipertanggungjawabkan sesuai dengan ketentuan peraturan perundang-undangan.

c) Kondisional. Sesuai dengan kondisi dan kemampuan pemberi dan penerima pelayanan dengan tetap berpegang pada prinsip efisiensi dan efektivitas.

d) Partisipatif. Mendorong peran serta masyarakat dalam penyelenggaraan pelayanan publik dengan memperhatikan aspirasi, kebutuhan dan harapan masyarakat.

\footnotetext{
${ }^{1}$ Valarie A. Zeethari, A. Patasuraman and Leonard L. Bery, Delivering Quality Service-Balancing Customer, Perception and Expectation, The Free Press, USA, 1990
} 
e) Kesamaan Hak. Tidak diskriminatif dalam arti tidak membedakan suku, ras, agama, golongan, gender dan status ekonomi.

f) Keseimbangan Hak dan Kewajiban. Pemberi dan penerima pelayanan publik harus memenuhi hak dan kewajiban masing-masing pihak.

Kualitas pelayanan (service quality) telah hampir menjadi faktor yang menentukan dalam menjaga keberlangsungan suatu organisasi birokrasi pemerintah maupun organisasi perusahaan. Telahlahir berbagai dimensi-dimensi mutu layanan agar dapat menciptakan mutu layanan yang prima serta zero defect dengan melakukan evaluasi serta perbaikan secara berkelanjutan (continuous improvement). Pelayanan yang baik dan sesuai dengan kebutuhan pengguna jasa publik, sangat penting dalam upaya mewujudkan kepuasan pengguna jasa publik (customer satisfaction) yang tentunya dalam rangka mewujudkan good governance (pemerintahan yang baik).

\section{Asas Good Governance}

Good governance (tata pemerintahan yang baik), pelayanan publik serta otonomi daerah adalah sebuah fenomena global yang pada prinsipnyaberbicara mengenai bagaimana pemerintah dapat mewujudkan good governance melalui pelayanan publik dalam era otonomi daerah. Konsepsi good governance adalah berangkat dari konsep Welfare State yang mempunyai tujuan nasional yaitu mensejahterakan masyarakat secara umum tanpa ada gap. Kesejahteraan terbentuk serta terwujud melalui pelayanan publik yang diberikan oleh pemerintah secara prima (pelayanan prima). Hakikat dasar pemerintah sebagai pelayan publik (public servant) harus dapat dirasakan oleh semua lapisan masyarakat. Dengan mendekatkan pemerintah dengan yang diperintah (desentralisasi) diharapkan dapat menjawab serta memenuhi harapan serta kebutuhan masyarakat tanpa terkecuali.(Fitriani 2017).

Pelayanan terkait dengan sistem, sumberdaya aparatur dan yang lebih pokok adalah paradigma berpikir yang melatari proses pelayanan itu diberikan kepada masyarakat. Penyelenggaraan pelayanan publik yang dilakukan oleh pemerintah (Aparatur Negara) masih dihadapkan pada sistem pemerintahan yang belum efektif dan efisien. Pada saat ini persoalan yang dihadapi begitu sangat mendesak, masyarakat sudah mulai cemas bahkan timbul rasa "tidak percaya" kepada pemerintah dengan mutu pelayanan aparatur yang makin menurun bahkan memburuk.

Konsep dari good governance melalui pelayanan publik tadi sulit diwujudkan manakala tidak memiliki kewenangan dan tanggung jawab untuk membuat keputusan sendiri dalam rangka mengatur dan mengurus kepentingan masyarakat menurut prakarsa sendiri berdasarkan aspirasi rakyat setempat sesuai dengan kondisi, potensi, dan karakteristik yang dimilikinya. Kewenangan dan tanggung jawab untuk membuat 
keputusan sendiri tadi sering disebut dengan istilah desentralisasi. Karenanya, menyoal "good governance" tidak bisa melepaskan diri dari masalah desentralisasi.(Prasojo \& Kurniawan 2018)

Penciptaan good governance dimaksudkan untuk meningkatkan akuntabilitas, responsivitas dan transparansi dalam penyelenggaraan pemerintahan dan negara dan inti dari upaya penciptaan good governance terletak pada reformasi birokrasi. Tidak adanya akuntabilitas dalam birokrasi di Indonesia merupakan faktor pendorong untuk melakukan reformasi birokrasi di Indonesia. Ketiadaan akuntabilitas ini menyebabkan penggunaan birokrasi sebagai mesin kekuasaan pemerintah. Akuntabilitas dalam birokrasi dimaksudkan, bahwa setiap aktivitas dan penggunaan dana yang dilakukan oleh pemerintah untuk kegiatan pemerintahan dan pembangunan harus dapat dipertanggungjawabkan (Prasojo \& Kurniawan 2018).

Arah baru atau model reformasi birokrasi perlu dirancang untuk mendukung demokratisasi dan terbentuknya clean and good governance yaitu tumbuhnya pemerintahan yang rasional, melakukan transparansi dalam berbagai urusan publik, memiliki sikap kompetisi antar departemen dalam memberikan pelayanan, mendorong tegaknya hukum dan bersedia memberikan pertanggungjawaban terhadap publik (public accountibility) secara teratur. (Soebhan 2000)

\section{Efektivitas Pelayanan Terpadu Satu Pintu}

Secara umum konsep efektivitas merupakan konsep untuk mengukur produktivitas, menunjukkan sampai seberapa jauh tercapainya suatu tujuan yang terlebih dahulu ditentukan. Kata efektif berasal dari bahasa Inggris "effective" yang artinya berhasil, sesuatu yang dilakukan berhasil dengan baik. Sejalan dengan arti kata tersebut, Robbins (dalam Tika, 2006 : 129) mendefinisikan efektivitas sebagai tingkat pencapaian organisasi jangka pendek dan jangka panjang. Kemudian efektivitas menurut Siagian (2004 : 151) adalah pemanfaatan sumber daya, dana, sarana dan prasarana dalam jumlah tertentu yang secara sadar ditetapkan sebelumnya untuk menghasilkan sejumlah barang atau jasa dengan mutu tertentu tepat pada waktunya

Berdasarkan beberapa pendapat tersebut, menunjukkan bahwa efektivitas adalah suatu ukuran sampai sejauhmana organisasi dapat melaksanakan seluruh tugastugasnya dan mencapai semua sasaran atau tujuannya. Apabila hal ini dikaitkan dengan masalah kerja pegawai, maka efektivitas dapat dipandang sebagai ukuran sampai sejauhmana para pegawai atau karyawan dapat melaksanakan seluruh pekerjaannya dalam rangka membantu organisasi mencapai sasaran atau tujuannya. Efektivitas merupakan suatu kegiatan atau tugas pokok yang dilaksanakan untuk 
mencapai tujuan organisasi dengan cara memaksimalkan tujuan agar sasaran yang dicapai dapat dinilai tepat dan terpadu.

Untuk melaksanakan tugas pokok sebagaimana dimaksud Badan Pelayanan Perijinan Terpadu mempunyai fungsi (BHARATA 2014) :

1. Perumusan dan pelaksanaan kebijakan teknis di bidang pelayanan perizinan terpadu;

2. Penyusunan dan pelaksanaan Rencana Strategi (Renstra) dan Rencana Kerja (Renja) di bidang pelayanan perizinan terpadu;

3. Penyelenggaraan pelayanan administrasi perizinan bidang Perekonomian, Pariwisata, Sosial Budaya dan Pekerjaan Umum;

4. Pelayanan koordinasi proses pelayanan perizinan bidang Perekonomian, Pariwisata, Sosial Budaya dan Pekerjaan Umum;

5. Pelaksanaan administrasi pelayanan perizinan;

6. Pemantauan dan evaluasi proses pemberian pelayanan perizinan;

7. Pelaksanaan pelayanan informasi dan pengaduan masyarakat di bidang pelayanan perizinan terpadu;

8. Pelaksanaan kegiatan di bidang pemungutan retribusi;

9. Pengelolaan administrasi umum meliputi penyusunan program, ketatalaksanaan, ketatausahaan, keuangan, kepegawaian, rumah tangga, perlengkapan, kehumasan, kepustakaan dan kearsipan;

10. Pelaksanaan Standard Pelayanan Minimal (SPM);

11. Penyusunan dan pelaksanaan Standard Pelayanan Publik (SPP);

12. Pelaksanaan fasilitas pengukuran Indeks Kepuasan Masyarakat (IKM) dan/atau pelaksanaan pengumpulan pendapat pelanggan secara periodik yang bertujuan untuk memperbaiki kualitas pelayanan;

13. Penyampaian data hasil pembangunan dan informasi lainnya terkait layanan publik secara berkala melalui website Pemerintah Daerah;

14. Pemberdayaan jabatan fungsional;

15. Pengevaluasian dan pelaporan pelaksanaan tugas pokok dan fungsi;

16. Pelaksanaan tugas lain yang diberikan oleh walikota sesuai dengan tugas dan fungsinya.

Peningkatan efektivitas pelayanan terpadu satu pintu harus dilihat dari aspek kemampuan suatu organisasi dalam mengadakan sosialisasi dan komunikasi dengan berbagai macam organisasi atau instransi.(Cahyaningrum n.d.) Mutu pelayanan tidak mungkin dapat dicapai tanpa partisipasi seluruh pemangku kepentingan. Untuk itu perlu saling memahami dan mengetahui peran dan posisi masing-masing pihak agar 
sinergi dalam mewujudkan pelayanan perizinan sebagaimana yang dicita-citakan bersama.

\section{Faktor Penghambat Pelayanan Terpadu Satu Pintu}

Tuntutan masyarakat untuk mendapatkan pelayanan yang berkualitas terus meningkat dari waktu ke waktu. Di dalam perkembangannya, pelaksanaan pembangunan di Provinsi Kalimantan Timur sering kali mengalami banyak hambatan. Tantangan yang dihadapi dalam pelayanan publik bukan hanya menciptakan sebuah pelayanan yang efisien, tetapi juga bagaimana pelayanan juga dapat dilakukan dengan tanpa membeda-bedakan status dari masyarakat yang dilayani. Dengan kata lain, bagaimana menciptakan pelayanan yang adil dan demokratis. Reformasi birokrasi publik pada pemerintah daerah dilaksanakan

tidak hanya mencakup pembenahan jika tidak disebut perombakan struktural menuju perampingan komponen birokrasi, sebagaimana diamanatkan dalam PP No. 8 Tahun 2003 tentang Pedoman Organisasi Perangkat Daerah.

Pola pikir masyarakat yang masih berfikir bahwa dalam hal penyediaan pelayanan perizinan petugas birokrasi sering kali memberikan prosedur yang sangat rumit dan cenderung berbelit-belit, sulit diakses, memiliki prosedur yang sangat rumit serta tidak adanya kepastian waktu dan keterbukaan biaya pelayanan yang dibutuhkan.

Jika mekanisme yang rumit terus tetap berjalan, otomatis membuat masyarakat menjadi malas dan enggan dalam mengurus perizinan. Pelaksanaan reformasi birokrasi dalam sistem pelayanan perizinan dilakukan dalam satu pintu, dengan adanya sosialisasi yang dilakukan oleh BPPMD .Pelayanan perizinan sebelumnya dilakukan di SKPD yang tersebar sesuai dengan jenis perizinan.

Keadaptasian sebagai kriteria efektivitas yang mengacu pada tanggapan organisasi terhadap perubahan eksternal dan internal. Perubahan-perubahan eksternal seperti persaingan, keinginan pelanggan, kualitas. Sedangkan perubahan internal adalah ketidakefisienan, ketiakpuasan, dan sebagainya merupakan adaptasi terhadap lingkungan.

Tentunya hal ini dapat diimbangi dengan keahlian SDM, namun apabila SDM yang ada ternyata tidak memiliki keahlian yang merasakan dampaknya adalah para pengusaha. Pengusaha harus mengeluarkan biaya lebih selain untuk kompensasi juga untuk pelatihan tenaga kerja baru yang tidak memiliki keahlian. Apabila kebiasaankebiasaan seperti itu apabila tidak segera ditangani akan menjadi budaya, tentunya apabila terjadi terus-menerus hal ini akan sangat tidak menguntungkan bagi para pengusaha. Dan dampak-dampak lain yang akan timbul adalah investor akan berfikir ulang untuk berinvestasi di daerah yang dituju. 
.Faktor-faktor yang mempengaruhi efektivitas pelayanan terpadu di daerah yaitu sistem pelayanannya sederhana dilayani dalam satu Kantor yaitu di BPPMD melalui Pelayanan Perizinan Terpadu (PTSP).

Untuk faktor penghambat pada khususnya biasanya hanya pada kurangnya kelengkapan syarat-syarat yang harus dipenuhi oleh publik, hal ini berarti ada pada masyarakat yang mengurus pelayanan. Disamping itu juga faktor penghambat adalah dari segi sarana prasarana penunjang dalam memberikan layanan.

Berikutnya, sing kali terjadi ketidaksesuaian penyelesaian pengkajian SKPD teknis dengan standar waktu yang telah ditetapkan melalui SPM, selain itu ketersediaan staf ahli yang ada pada instansi teknis terkait ketika adanya permohonan izin masuk dalam lingkup kewenangannya untuk segera memproses pengkajian terhadap permohonan tersebut menjadi kendala, karena dengan posisi staf ahli yang tidak berkedudukan tetap di kantor KP2T dan masih bertempat di SKPD teknis terkait, akibatnya hal tersebut menyebabkan para staf teknis terkadang sedang melaksanakan tugas lain yang telah diberikan SKPD teknisnya sendiri.

Disisi lain permohonan izin pada SKPD tertentu seperti BKPM (Penanaman Modal) tidak menentu kapan datangnya sehingga menjadi dilematis mengenai perlu atau tidaknya staf teknis ditempatkan secara organik pada kantor KP2T tersebut. Selanjutnya terdapat pula permasalahan dimana sering terjadinya rotasi pegawai yang sulit dihindarkan pada instansi SKPD induk yang menangani proses pengkajian teknis permohonan. Padahal pegawai yang dirotasi oleh SKPD induk tersebut telah dibekali berbagai pelatihan khusus oleh PTSP sehingga adanya rotasi pegawai membuat PTSP harus memberi pelatihan lagi kepada pegawai yang baru dirotasi, hal tersebut mengakibatkan inefisiensi terhadap pengembangan dan pengelolaan SDM instansi induk yang akan membantu pelaksanaan dengan PTSP. (Hafiz 2014).

\section{Harmonisasi Antar Lembaga (Reformasi Birokrasi dalam Good Governance)}

United Nations Development Programme (UNDP) merumuskan istilah governance sebagai suatu exercise dari kewenangan politik, ekonomi dan administrasi untuk menata, mengatur dan mengelola masalah-masalah sosialnya, istilah governance menunjukan suatu proses dimana rakyat bisa mengatur ekonominya, institusi dan sumber-sumber sosial dan politiknya, tidak hanya digunakan untuk pembangunan, tetapi juga untuk menciptakan kohesi, integrasi, dan untuk kesejahteraan rakyatnya. Pada akhirnya tujuan pemberdayaan adalah tumbuhnya kesetaraan (equal) antara rakyat (citizen) atau civil society dan pemerintah sesuai dengan peran dan fungsinya masing-masing (Rustan n.d.). 
Hans Dieter Evers melihat bahwa proses birokrasi di Indonesia berkembang model birokrasi ala Parkinson dan ala Orwel. Birokrasi ala Parkinson adalah pola dimana terjadi proses pertumbuhan jumlah personil dan pemekaran struktural dalam birokrasi secara tidak terkendali. Sedang birokrasi ala Orwel adalah pola birokratisasi sebagai proses perluasan kekuasaan Pemerintah dengan maksud mengontrol kegiatan ekonomi, politik dansosial dengan peraturan, regulasi dan bila perlu melalui paksaan ${ }^{2}$.

Cap birokrasi Indonesia seperti itu ternyata bukan sampai di situ saja, tetapi melalui pendekatan budaya birokrasi Indonesia masuk dalam kategori birokrasi patrimonial. Ciri-ciri dari birokrasi patrimonial adalah (1) para pejabat disaring atas dasar kriteria pribadi; (2) jabatan dipandang sebagai sumber kekayaan dan keuntungan; (3) para pejabat mengontrol baik fungsi politik maupun fungsi administrasi; dan (4) setiap tindakan diarahkan oleh hubungan pribadi dan politik.(Lili Romli n.d.)

Fenomena birokrasi lainnya yang terjadi secara umum, yakni terkait keluhan dan persepsi masyarakat tentang pelayanan. Hal ini tercermin dari beberapa permasalahan (HENRIYANI 2007) sebagai berikut :

1. Masih ada aparatur yang tidak disiplin dalam penggunaan waktu untuk penyelesaian suatu urusan. Seperti terjadi pada pelayanan administratif (KTP, KK) dan pelayanan perizinan yang terkadang memakan waktu lama melebihi batas waktu yang ditentukan.

2. Masih ada anggapan masyarakat bahwa berhubungan dengan birokrasi, berarti berhubungan dengan prosedur yang berbelit- belit. Hal ini terjadi karena terbatasnya informasi persyaratan pelayanan.

3. Masih ada kegiatan/aktivitas program pemerintah yang belum efektif dan efisien.

Ditinjau dari dimensi politik, dapat diketahui bahwa penyelenggaraan demokrasi dalam pemerintahan di daerah, mempergunakan cara demokrasi perwakilan. Ini mengandung arti bahwa penyelenggaraan pemerintahan secara intensif tidak dijalankan secara langsung oleh masyarakat sebagai stakeholder utama pemerintahan daerah, tetapi dijalankan wakil masyarakat yang dipilih setiap lima tahun sekali. Wakil masyarakat ini terdiri dari dua organ, yakni wakil rakyat di Dewan Perwakilan Rakyat Daerah dengan tugas utama menjalan hak mengatur daerah (policy making); dan wakil rakyat yang duduk sebagai Kepala Daerah dan Wakil Kepala Daerah yang tugas utamanya mengatur dan mengurus. Mengurus berarti memimpin perangkat daerah untuk menjalankan kebijakan yang sudah dibuat. (Kabir 2016).

\footnotetext{
${ }^{2}$ Hans-Dieter Evers dan Tilman Schiel, Kelompok-Kelompok Strategis: Studi Perbandingan tentang Negara, Birokrasi, dan Pembentukan Kelas di Dunia Ketiga, Jakarta: Yayasan Obor Indonesia, 1990, hal, 228.
} 
Fenomena demokrasi dan globalisasi berdampak pada reformasi politik di Indonesia, khususnya pada sistem pemerintahan yang mengalami transformasi dari sistem sentralistik menjadi desentralistik. Sistem pemerintahan desentralistik menuntut adanya pendelegasian wewenang dari Pemerintah ke Pemerintah Daerah, dan selanjutnya kebijakan desentralisasi ini dituangkan dalam Undang-undang Nomor 32 tahun 2004 dan direvisi menjadi Undang-undang Nomor 23 tahun 2014 tentang Pemerintahan Daerah. Kebijakan desentralisasi dengan wujud otonomi daerah bertujuan untuk meningkatkan kesejahteraan rakyat melalui pemerataan pembangunan, peningkatkan daya saing daerah, keadilan, keistimewaan dan kekhususan serta potensi dan keanekaragaman daerah dalam sistem Negara Kesatuan Republik Indonesia. (Haridsyah Batubara n.d.)

Reformasi yang berlangsung telah memberikan warna dan pengaruh pada perkembangan administrasi publik yaitu untuk menempatkan kembali fungsi aparatur pemerintahan selaku pelayan publik (public servant). Dalam kedudukan selaku pelayan publik maka secara total penyelenggaraan pemerintahan dan pembangunan, termasuk didalamnya pemerintahan dan pembangunan daerah ditujukan untuk pelayanan terhadap masyarakat. Dengan demikian untuk mencapai tujuan pemerintahan dan pembangunan harus dibarengi dengan peningkatan kinerja pengelolaan pelayanan publik. Dalam konteks otonomi daerah, konsep pengukuran kinerja merupakan salah satu tolok ukur kemampuan aparatur pemerintah daerah (Pemda) dalam melaksanakan kewenangannya (Enceng 2019).

Kontrol sosial terhadap kinerja organisasi publik merupakan bagian tak terpisahkan dari kehidupan masyarakat demokratis. Sebagaimana diungkapkan Wasistiono (Kadir et al. 2010), bahwa kontrol sosial dapat efektif apabila memenuhi prasyarat berikut :

1. Pemerintahannya bersifat demokratis, tidak otoriter dan represif;

2. Telah terbangun kelas menengah yang cukup banyak jumlahnya dan solid serta memiliki kepedulian sosial;

3. Adanya peraturan perundang- undangan yang jelas mengenai mekanisme kontrol sosial sehingga tidak terjadi anarki;

4. Adanya kesadaran yang meluas dari masyarakat mengenai hak dan kewajibannya sebagai warga negara ataupun warga masyarakat

Pelayanan publik yang prima (excellent) merupakan tanda dari kesadaran baru dari pemerintah atas tanggung jawab utama dalam mengelola pemerintahan dan memenuhi segala kebutuhan masyarakat agar pelayanan yang diberikan aparatur pemerintah dapat lebih memuaskan masyarakat pengguna layanan, maka perlu 
perubahan mindset dari seluruh aparatur pelaksana pelayanan publik sebagai langkah awal dalam memberikan pelayanan yang prima tersebut.(Nuriyanto 2014) Aparatur pelayanan publik atau birokrasi yang selama ini didesain untuk bekerja lambat, terlalu berhati-hati dan procedural minded sudah tidak bisa lagi diterima oleh masyarakat pengguna layanan yang membutuhkan pelayanan yang cepat, efisien, tepat waktu, dan simple (seperti orang yang mengurusi bisnis atau investasi). Ditambah lagi sekarang kita memasuki era globalisasi yang penuh dengan kompetisi, sehingga gerak yang cepat dan tindakan yang tepat dari aparat pemerintah merupakan suatu keharusan (necessity).

Standar pelayanan publik (selanjutnya disebut SPP) merupakan standar pelayanan yang wajib disediakan oleh pemerintah kepada masyarakat. Adanya SPP akan menjamin pelayanan minimal yang berhak diperoleh warga masyarakat dari pemerintah. Dengan kata lain, SPP merupakan tolok ukur untuk mengukur kinerja penyelenggaraan kewenangan wajib yang berkaitan dengan pelayanan dasar kepada masyarakat seperti: kesehatan, pendidikan, air minum, perumahan dan lain-lain. Di samping SPP untuk kewenangan wajib, daerah dapat mengembangkan dan menerapkan standar kinerja untuk kewenangan daerah yang lain. ${ }^{3}$

Dengan SPP akan terjamin kualitas minimal dari suatu pelayanan publik yang dapat dinikmati oleh masyarakat untuk memenuhi kebutuhan hidupnya. Dengan demikian, akan terjadi pemerataan pelayanan publik dan terhindar dari kesenjangan pelayanan yang diberikan antara daerah yang satu dengan daerah lainnya. Akan tetapi dalam menerapkan konsep SPP harus dibedakan antara pemahaman tentang SPP dan persyaratan teknis dari suatu pelayanan.

\section{Simpulan}

Kewenangan yang dimiliki KP2T ialah untuk penandatangan perizinan dan non (bukan) perizinan, dalam suatu sistem Pelayanan Terpadu Satu Pintu. Kewenangan tersebut sendiri termasuk kewenangan penerbitan dan/atau pencabutan atau pembatalan, dan penarikan retribusi perizinan. Selanjutnya disebutkan bahwa perizinan dilaksanakan berdasarkan rekomendasi dan/atau pertimbangan teknis dari Dinas atau Badan atau SKPD teknis terkait yang membidangi perizinan dan non (bukan) perizinan yang bersangkutan. Yang mana secara umum PTSP yang dilaksanakan oleh KP2T merujuk pada Permendagri No 24 tahu 2006 mengenai PTSP, sektor yang dialihkan sendiri melalui pendelegasian kewenangan perizinan dan non perizinannya menjadi 14 sektor dengan yang mencapai 88 jenis izin dan non izin.

\footnotetext{
${ }^{3}$ Soeparto Wijoyo, Pelayanan Publik dari Dominasi ke Partisipasi, Airlangga University Press, 2006, h.2.
} 
Adanya peralihan kewenangan tersebut mengakibatkan tanggung jawab yuridis tidak lagi berada ditangan Kepala Daerah, tetapi beralih kepada Kepala Kantor Pelayanan dan Perizinan Terpadu Daerah. Karena tanggung jawab terhadap wewenang yang telah di delegasikan berada ditangan Kepala Kantor Pelayanan dan Perizinan Terpadu selaku delegataris pada kewenangan tersebut serta bagaimana proses pengaturan peralihan kewenanganya telah sesuai dengan kaedah hukum yang ada.

\section{Daftar Pusataka}

BHARATA, H.A. 2014, 'Harmonisasi Kewenangan Pengurusan Izin Keramaian Antara Kepolisian Dan Pemerintah Kota Malang', Universitas Brawijaya Fakultas Hukum, vol. 2014, pp. 561-5.

Cahyaningrum, D. n.d., Harmonisasi Pengaturan Kewenangan Pemerintah Pusatdan Pemerintah Daerah Dalam Penyelenggaraan Urusan Di Bidang Penanaman Modal.

Enceng, L.B.\& P.M. 2019, Meningkatkan Kompetensi Aparatur Pemerintah Daerah dalam Mewujudkan Good Governance, pp. 33-43.

Febliany, I., Fitriyah, N. \& Paselle, E. 2014, Efektivitas Pelayanan Terpadu Satu Pintu Terhadap Penyerapan Investasi Di Kalimantan Timur (Studi Pada Badan Perijinan Dan Penanaman Modal Daerah Provinsi Kalimantan Timur) Imelda, vol. 2, no. 3, pp. 410-20.

Fitriani, D.R. 2017, Mewujudkan Good Governance melalui Pelayanan Publik dalam Era Otonomi Daerah Dini Rizki Fitriani Dosen Fakultas Ilmu Administrasi Negara Universitas Subang, vol. III, no. April, pp. 324-30.

Hafiz, F. 2014, Pintu Terkait Perizinan Dan Non Perizinan Di Bidang Penanaman Modal ( Studi Pelayanan Terpadu Satu Pintu Di Pemerintah Daerah Provinsi Bengkulu ) Fadhly Hafiz Implementation of One Stop Services Authority Related to Licensing and non Licensing in the Fiel.

HARIDSYAH BATUBARA, S. n.d., Penerapan Tata Kelola Pemerintahan Yang Baik Dalam Penyelenggaraan Pengadaan Barang Dan Jasa ( Studi Di Dinas Pekerjaan Umum Provinsi Kalimantan Barat), pp. 1-31.

HENRIYANI, E. 2007, 'Pengawasan Masyarakat Dan Kinerja Birokrasi Pemerintah', Jurnal FISIP-Universitas Galuh Ciamis, vol. 67, no. 6, pp. 14-21.

Kadir, A.G., Pemerintahan, I., Hasanuddin, U., Nurlinah, H., Pemerintahan, I. \& Hasanuddin, U. 2010, Analisis Hubungan Pemerintah Pusat dan Daerah; Studi Kasus Perimbangan Keuangan Kota Makassar Muh Shujahri Am ( Mahasiswa Ilmu Pemerintahan Universitas Hasanuddin ), vol. 3, pp. 37-42.

Lili Romli n.d., 'Masalah Reformasi Birokrasi', Jurnal Kebijakan dan Manajemen ONS.

Marom, A. 2015, 'Inovasi Birokrasi Pelayanan Publik Bidang Sosial Tenaga Kerja Dan Transmigrasi Di Kabupaten Kudus', Gema Publica, vol. 1, no. 1, p. 45.

Nuriyanto 2014, 'Penyelenggaraan Pelayanan Publik Di Indonesia, Sudahkah Berlandaskan Konsep “Welfare State ”?', Jurnal Konstitusi, vol. 11, no. 3, pp. 429-253.

Prasojo, E. \& Kurniawan, T. 2018, 'Bureaucracy Reform and Good Governance: the case of the best practices from several regions in Indonesia', Symposium A Quarterly Journal In Modern Foreign Literatures, pp. 1-15.

Rustan, A. n.d., 'Partisipasi Masyarakat dalam Melakukan Kontrol terhadap Penyelenggaraan Pemerintah Daerah', Pelaksana Bidang Kajian PKP2A III LAN Samarinda.

Soebhan, S.R. 2000, 'Model Reformasi Birokrasi Indonesia', Ppw Lipi, pp. 1-10. 
Busrizalti, 2013, Hukum Pemda Otonomi Daerah dan Implikasinya, Total Media Yogyakarta

Valarie A. Zeethari, A. Patasuraman and Leonard L. Bery, 1990, Delivering Quality Service-Balancing Customer, Perception and Expectation, The Free Press, USA

Hans-Dieter Evers dan Tilman Schiel, 1990, Kelompok-Kelompok Strategis: Studi Perbandingan tentang Negara, Birokrasi, dan Pembentukan Kelas di Dunia Ketiga, Jakarta: Yayasan Obor Indonesia,

Soeparto Wijoyo, 2006, Pelayanan Publik dari Dominasi ke Partisipasi, Airlangga University Press 